\title{
Roboty a psychologia (ekologiczna). Wprowadzenie
}

\author{
Witold Wachowski \\ Ośrodek Badań Filozoficznych w Warszawie \\ w[]avant.edu.pl \\ Otrzymano i zaakceptowano: czerwiec 2014; opublikowano: lato 2014.
}

\begin{abstract}
Abstrakt
Niniejsze krótkie wprowadzenie do artykułu „Afordancje dla robotów” autorstwa Thomasa E. Hortona, Arpana Chakraborty'ego i Roberta St. Amanta skoncentrowane jest na możliwościach współpracy robotyki z psychologią ekologiczną.
\end{abstract}

Słowa kluczowe: afordancja; robotyka; podmiot działający; psychologia ekologiczna; Gibson.

Postać robota (z akcentem na „postać”) niewątpliwie pobudza wyobraźnię. A z uwagi na ciągoty humanoidalne tych wyobrażeń wystarczy, że robot będzie posiadał jakąkolwiek atrapę twarzy, by nas wewnętrznie poruszył, choćby jego wyposażenie i inteligencja nie przekraczały poziomu porządnej pralki (ba! choćby był nawet zepsuty). I nie jest to wcale kwestia błaha, zważywszy na fakt, że trwają już zaawansowane prace projektowe nad robotami zdolnymi do pewnego rodzaju interakcji społecznych. A nie trzeba chyba przekonywać, jakie znaczenie psychologiczne w takich interakcjach ma dla ludzi powierzchowność danego osobnika, przede wszystkim - stopień podobieństwa do przedstawicieli ich gatunku, co uzupełnione zostaje dynamiką sytuacyjną (zob. np. Alač 2013: 133-177; Kröger i in. 2011: 82-93).

Kiedy jednak przyjrzymy się bliżej pracy robotyków, budowie i funkcjonowaniu robotów oraz napotykanym w tym kontekście problemom, akcent przenosi się z kwestii typu udawanie czy wyręczanie człowieka na bardziej szczegółowe, techniczne, związane między innymi z mechanizmami interakcji robota z narzędziami i innymi elementami jego środowiska. I jeżeli na tym poziomie ma coś do zrobienia psychologia, to idealnym kandydatem wydaje się tak zwana psychologia ekologiczna. 
Wyciąganie konsekwencji z usytuowania podmiotu w danym środowisku jest pod pewnymi względami niezależne od tego, czy jest to osobnik żywy, czy sztuczny. Zmniejszeniu ulega nacisk na centralny system sterowania, za to planowanie i działanie są tutaj silnie powiązane. Ponadto podmiot nie otrzymuje na starcie pakietu instrukcji wszelkiego postępowania, ponieważ może się wielu zachowań nauczyć już w kontakcie z własnym środowiskiem.

Ilustracja 1

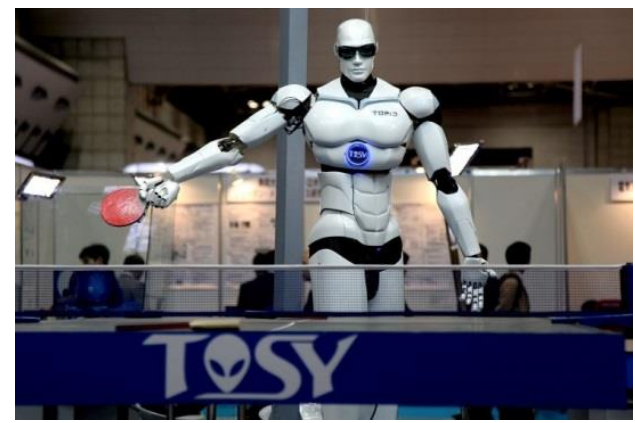

Humanoidalny robot TOPIO grający w ping ponga

(a inaczej patrząc: umięśniony celebryta w dizajnerskich

okularach podbija serca widowni). [CC BY-SA 3.0]

To, na jakie zachowania to środowisko pozwala, zależy zarówno od cech i możliwości fizycznego ciała osobnika - zwykle niezależnych od niego i pod wieloma względami niezmiennych - jak i od tego, czego może się ów osobnik nauczyć, a tu już otwiera się pewna pula możliwości, prawdopodobnie nieskończonych.

A więc jeśli na przykład dla organizmu lub robota (zob. Ilustracja 2) o ciele wydłużonym i bez funkcjonalnych kończyn nie pozostaje przemieszczać się inaczej niż wijąc się czy pełzając, wówczas wykorzysta on te właściwości podłoża, dzięki którym będzie w stanie optymalnie poruszać się wijąco-pełzająco (niestety nie wiem, czy wąż preferuje właściwości dywanu, czy parkietu). Podobnie jest $\mathrm{z}$ wykorzystaniem cech narzędzi stosownie do możliwości manipulacyjnych kończyn osobnika, który się nimi posłuży.

Ilustracja 2

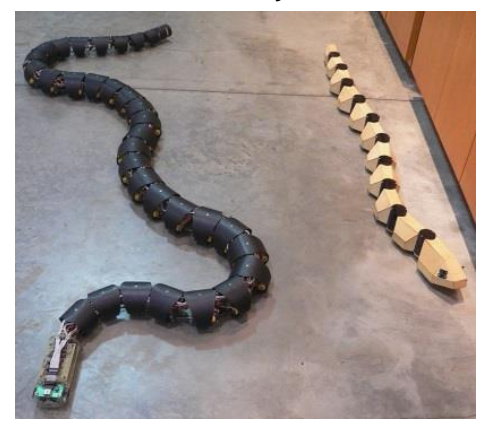

Z cyklu: roboty, gdzie się nie ruszysz.

Tu: robotyczne węże. [CC BY 2.0] 
Zauważmy, że nie zastanawiamy się tutaj nad kwestią tego, czy roboty mogą być świadome, na ile staną się odpowiedzialne lub też czy będą kiedyś zdolne rozzłościć się i nas stłuc. Rozważamy za to możliwości relatywnie samodzielnego odnajdywania się robota w jego środowisku, uczenia się w nim, testowania tkwiących w nim możliwości.

Ilustracja 3

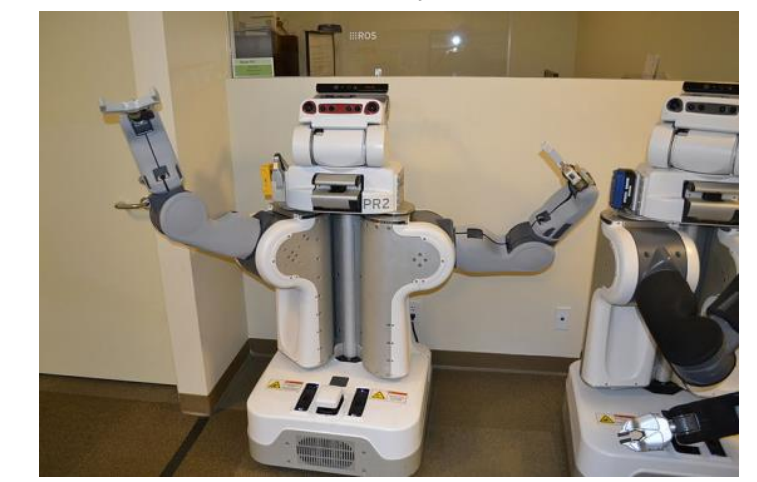

PR2 - robot może niegrzeszący urodą, za to z niebywale zaawansowaną zdolnością chwytania. [CC-BY-SA-3.0]

Niektórzy dzisiejsi robotycy (czyli pracujący nad robotami jutra) coraz bardziej doceniają właściwości obiektów zwane afordancjami, które skłaniają osobnika do wykonania określonych działań (Zaier 2012: 153). W tym momencie wprowadzone zostaje pojęcie, które tylko z pozoru łączy i brata społeczność robotyków ze społecznością psychologów ekologicznych. Kariera pojęcia afordancji - pierwotnie podstawy teorii Jamesa J. Gibsona - może budzić trochę zastrzeżeń. Zarówno dlatego, że nie było ono ukochanym dzieckiem głównego nurtu psychologii i z tego powodu odbyło małą tułaczkę po innych dziedzinach, jak i dlatego, że do dziś nie doczekało się w miarę precyzyjnej i niekontrowersyjnej definicji (zob. np. Klawiter 2012: 261-266; Dotov i in. 2012: 282-295). A jednak - jak pokazują autorzy prezentowanego poniżej artykułu - to pojęciowe enfant terrible nie odstraszyło badaczy sztucznej inteligencji i konstruktorów robotów; choć oczywiście trudno tutaj mówić o gładkiej, bezproblemowej ich współpracy z psychologami ekologicznymi.

Afordancje zdążyły zrobić już pewną karierę w dziedzinie projektowania artefaktów, także na potrzeby przemysłowe; dały o sobie znać w badaniach nad interakcjami człowiek-komputer; stały się składnikiem dociekań nad relacjami kulturowymi (zob. np. Norman 1988; Hartson 2003: 315-338; Costall 2012: 296-304). Jak już wiemy, wykorzystywane są też w robotyce, w wielu przypadkach - bez bezpośredniego związku z teorią Gibsona. Czy aby w tych różnych przypadkach nadal mowa o tym samym pojęciu lub przynajmniej bliżej spokrewnionej rodzinie pojęć? Zapewne nadrzędna potrzeba lepszego zrozumienia sprzężonych systemów podmiot-środowisko jest tutaj w jakiś sposób wiążąca. 


\title{
Literatura
}

Alač, M., Movellan, J. i Tanaka, F. Jak uspołecznić robota: Organizacja przestrzenna i multimodalne interakcje semiotyczne $\mathrm{w}$ laboratorium robotyki społecznej. Przeł. Ł. Afeltowicz. Avant, IV, 1/2013: 133-177.

Costall, A. 2012. Afordancje kanoniczne w kontekście. Przeł. K. Bielecka. Avant, III, 2/2012: 296-304.

Dotov, D.G., Nie, L. i de Wit, M. 2012. Zrozumieć afordancje: przegląd badań nad główną tezą Jamesa J. Gibsona. Przeł. D. Lubiszewski i N. Strehlau. Avant, III, 2/2012: 282-295.

Hartson, H.R. 2003. Cognitive, physical, sensory, and functional affordances in interaction design. Behaviour \& Information Technology, Vol. 22, No. 5: 315338.

Horton, T.E., Chakraborty, A. i Amant, R.S. 2014. Afordancje dla robotów: krótki przegląd. Avant, V, 1/2014: 133-150.

Klawiter, A. 2012. Co ze mną zrobisz, kiedy mnie zobaczysz? Percepcja jako wyszukiwanie ofert (affordances) w otoczeniu. Avant, III, 2/2012: 261-266.

Kröger, B.J., Birkholz, P. i Neuschaefer-Rube, Ch. 2011. Towards an articulation-based developmental robotics approach for word processing in face-toface communication. Paladyn, Volume 2, Issue 2: 82-93.

Norman, D. 1988. The Psychology of Everyday Things. Basic Books.

Zaier, R., red. 2012. The Future of Humanoid Robots - Research and Applications. InTech. Źródło: www.intechopen.com

Źródło wszystkich ilustracji: http://en.wikipedia.org

\begin{abstract}
The paper is a short introduction to the article "Affordances for robots" by Thomas E. Horton, Arpan Chakraborty and Robert St. Amant, in the context of applications of ecological psychology.
\end{abstract}

Keywords: affordance; robotics; agent; ecological psychology; Gibson. 